\title{
Companion Study Relationship Registration Required Indicator
}

National Cancer Institute

\section{Source}

National Cancer Institute. Companion Study Relationship Registration Required Indicator. NCl Thesaurus. Code C93750.

Specifies whether registration to the companion study is mandatory when registering to the parent study. 